\title{
THE
}

\section{Risk stacking of pneumococcal vaccination indications increases mortality in unvaccinated adults with Streptococcus pneumoniae infections}

Jacob B. Morton

University of Rhode Island

J. Morrill

University of Rhode Island

Kerry L. LaPlante

University of Rhode Island, kerrylaplante@uri.edu

Aisling R. Caffrey

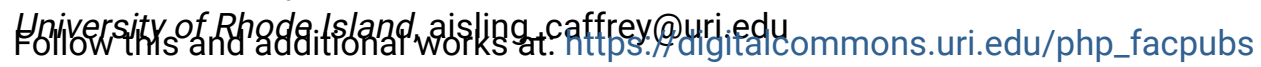

The University of Rhode Island Faculty have made this article openly available. Please let us know how Open Access to this research benefits you.

This is a pre-publication author manuscript of the final, published article.

Terms of Use

This article is made available under the terms and conditions applicable towards Open Access Policy Articles, as set forth in our Terms of Use.

\section{Citation/Publisher Attribution}

Morton, J. B., Morrill, H. J., LaPlante, K. L., \& Caffrey, A. R. (2017). Risk stacking of pneumococcal vaccination indications increases mortality in unvaccinated adults with Streptococcus pneumoniae infections. Vaccine, 35(13), 1692-1697. doi: 10.1016/j.vaccine.2017.02.026

Available at: http://dx.doi.org/10.1016/j.vaccine.2017.02.026 
Risk stacking of pneumococcal vaccination indications increases mortality in unvaccinated adults with Streptococcus pneumoniae infections

Jacob B. Morton ${ }^{1,2}$, Haley J. Morrill ${ }^{1,2}$, Kerry L. LaPlante ${ }^{1,2,3}$, and Aisling R. Caffrey ${ }^{1,2,4}$

1. Veterans Affairs Medical Center, Infectious Diseases Research Program and Center of Innovation in Long Term Services and Supports, Providence, RI

2. University of Rhode Island, Department of Pharmacy Practice, College of Pharmacy, Kingston, RI

3. Warren Alpert Medical School of Brown University, Division of Infectious Diseases, Providence, RI

4. Brown University School of Public Health, Providence, Rhode Island

Address Correspondence: Aisling R. Caffrey, Ph.D., MS, Assistant Professor, University of Rhode Island; 7 Greenhouse Road, Kingston, RI 02881; office: 401874-5320; e-mail: Aisling_Caffrey@uri.edu

Manuscript word count: 2,788 


\section{Abstract}

2 Background: Several chronic disease states have been identified as

3 pneumococcal vaccination indications due to their ability to increase

4 pneumococcal disease development and subsequent mortality. However, the risk

5 of mortality according to the number of these disease states present is unknown.

6 We sought to determine the impact of concomitant, multiple risk factors (stacked

7 risks) for pneumococcal disease on 30-day mortality in adults.

9 Methods: This was a national case-control study of unvaccinated older Veterans

10 ( $\geq 50$ years of age) admitted to Veterans Affairs medical centers from 2002 to 2011

11 with serious pneumococcal infections (pneumonia, bacteremia, meningitis) based

12 on positive $S$. pneumoniae blood, cerebrospinal fluid, or respiratory cultures,

13 respectively. Cases were those not alive 30 days following culture, while controls

14 were alive. Using logistic regression, we quantified risk of 30-day mortality among

15 patients with stacked risk factors, including age $\geq 65$ years, alcohol abuse, chronic

16 heart disease, chronic liver disease, chronic respiratory disease, diabetes mellitus,

17 immunodeficiency, and smoking.

19 Results: We identified 9,730 serious pneumococcal infections, with an overall 30-

20 day mortality rate of $18.6 \%$ (1,764 cases, 7,966 controls). Infection types included

21 pneumonia (62\%), bacteremia (26\%), and bacteremic pneumonia (11\%). Along

22 with eight individual risk factors, we assessed 247 combinations of risk factors.

23 Most cases (85\%) and controls (74\%) had at least two risk factors. Mortality 
24 increased as risks were stacked, up to six risk factors (one: OR 1.5, Cl 1.08-2.07;

25 two: OR 2.01, Cl 1.47-2.75; three: OR 2.71, Cl 1.99-3.69; four: OR 3.27, Cl 2.39-

26 4.47; five: OR 3.63, Cl 2.60-5.07; six: OR 4.23, Cl 2.69-6.65), with each additional

27 risk factor increasing mortality an average of $55 \%( \pm 13 \%)$.

28

29 Conclusions: Among adults $\geq 50$ years with serious pneumococcal disease,

30 mortality risk increased approximately $55 \%$ as vaccination indications present

31 increased. Mortality with six stacked indications was double that of two indications.

32

33 Keywords: Risk Stacking, Pneumococcal Vaccination, Streptococcus

34 pneumoniae, Mortality

35 


\section{Introduction}

37 Serious Streptococcus pneumoniae infections, including pneumonia,

38 bacteremia, and meningitis, are a major cause of morbidity and mortality among

39 older adults.[1-3] Since the 1980s, vaccines to prevent pneumococcal disease

40 have been used on a global scale to mitigate the risks associated with these

41 bacterial infections.[4] The Advisory Committee on Immunization Practices (ACIP)

42 recommends administration of the pneumococcal vaccination to adults with certain

43 risk factors for pneumococcal disease, including age $\geq 65$ years, alcoholism, heart

44 disease and heart failure, chronic respiratory disease, hepatic dysfunction,

45 immunodeficiency, and smoking, in an effort to prevent invasive pneumococcal

46 disease (IPD) and subsequent poor outcomes.[3]

47 Recent research has revealed that the presence of multiple, concomitant

48 risk factors (risk stacking), particularly those conditions identified by ACIP as

49 indications for pneumococcal vaccination, increases the likelihood of developing

50 pneumococcal disease beyond the risk posed by individual risk factors alone. $[5,6]$

51 As our population ages, it is becoming more common for patients to have two or

52 more risk factors.[6] However, the impact of risk stacking on outcomes, namely

53 mortality, of adults who end up developing pneumococcal disease remains

54 unknown. Furthermore, current data on risk stacking are limited in that there is no

55 information regarding the impact of risk stacking "at-risk" conditions (e.g.,

56 alcoholism, heart disease, liver disease, cigarette smoking) with "high-risk"

57 conditions (e.g., immunodeficiency).[5-7] As such, the purpose of this study was 
58 to quantify the impact of stacking risk factors for developing pneumococcal disease

59 on 30-day mortality among unvaccinated older adults.

60

\section{Methods}

62 Using national Veterans Health Administration databases, we conducted a 63 nested case-control study of older Veterans (age $\geq 50$ years) with positive $S$.

64 pneumoniae blood, cerebrospinal fluid, or respiratory cultures between January 1 ,

652002 and December 31, 2011. We defined serious pneumococcal infections as 66 culture-positive pneumonia, bacteremia, and meningitis. Cases were those

67 individuals who died from any cause within 30 days of positive culture, and controls

68 were those alive at 30 days. Patients were allowed to be included in the study

69 multiple times if they had multiple positive cultures. Positive cultures from the same

70 patient within a 30-day period were considered the same infection. We utilized

71 national VA datasets, created from electronic medical records and administrative

72 data, to collect patient demographics, health factors, medical history, vaccination

73 history, medication use, clinical outcomes, and culture data. Pneumonia was

74 identified from positive sputum cultures in addition to International Disease

75 Classification, Ninth Revision (ICD-9) diagnosis codes. Bacteremia and meningitis

76 were defined by positive blood and cerebrospinal fluid cultures, respectively.

77 Patients receiving a pneumococcal vaccination within five years of positive culture

78 were excluded. We utilized ICD-9 and procedure codes to identify the presence of

79 disease states within one year of the positive culture date. Medication use within

8030 days of positive culture, particularly the use of immunosuppressants 
81 (corticosteroids, monoclonal antibodies, antineoplastic agents), was also 82 assessed.

83 We quantified the impact of individual, as well as combinations of multiple 84 risk factors (stacked risks) for developing pneumococcal disease on 30-day all85 cause mortality. Selected risk factors were those that were previously identified as

86 commonly occurring among older Veterans with pneumococcal disease, and that

87 were also indications for pneumococcal vaccination identified by ACIP.[1, 3] These

88 included age $\geq 65$ years (age), alcohol abuse, chronic heart disease including

89 chronic heart failure (CHD), chronic liver disease (CLD), chronic respiratory

90 disease, including asthma and chronic obstructive pulmonary disease (CRD),

91 diabetes mellitus (DM), immunodeficiency (IC), and smoking.[3] Age was included

92 as a dichotomous variable, as opposed to a continuous variable, to reflect the

93 actual vaccination indication of age $\geq 65$ years. Immunodeficiency was defined as

94 the presence of a solid malignancy, hematologic malignancy, HIV, or an AIDS-

95 defining illness within one year of positive culture. Smoking status was defined as

96 documentation of active cigarette smoking, smoking cessation counseling, or

97 receipt of smoking cessation prescription products (varenicline, nicotine

98 replacement products) within one year of positive culture. We determined all

99 possible two, three, four, five, six, seven, and eight indication combinations and

100 defined each combination as a unique variable. Odds ratios (ORs) and 95\%

101 confidence interval (Cls) were calculated using logistic regression. Separate

102 models were run for each mutually exclusive combination of vaccine indications.

103 The reference group for each model consisted of those individuals without any of 
104 the aforementioned risk factors. This common reference group was selected in

105 order to quantify the impact of stacking different combinations of indications as

106 compared to those with none of the aforementioned indications for vaccination.

107 Risk factors were deemed significant at a two-tailed $p$-value of 0.05 or less. All

108 statistical analyses were performed with SAS version 9.2 (SAS Institute Inc., Cary,

109 NC, USA).

110 Approval by the Institutional Review Board and Research and Development

111 Committee of the Providence Veterans Affairs Medical Center was obtained prior

112 to initiating the study.

113

\section{Results}

115 We identified 9,730 serious pneumococcal infections in 9,468 unvaccinated

116 individuals, with a 30 -day mortality rate of $18.6 \%$ (1,764 cases and 7,966 controls;

117 Table 1). The primary infection types, determined from positive cultures, included

118 pneumonia (cases $n=871,49.4 \%$; controls $n=5,204,65.3 \%$ ), bacteremia (cases

$119 n=585,33.2 \%$; controls $n=1,969,24.7 \%$ ), and bacteremic pneumonia (cases

$120 n=305,17.3 \%$; controls $n=755,9.5 \%)$. Meningitis accounted for $<1 \%$ of infections

121 among cases and among controls.

122 There were 574 episodes (5.9\%; 49 cases, $2.8 \%, 525$ controls, $6.6 \%$ ) of

123 pneumococcal disease among individuals with none of the eight aforementioned

124 risk factors. In addition to the eight individual risk factors, there were 247 unique

125 combinations of risk factors. There were three individual risk factors (age, CHD,

126 and IC) and 89 stacked risks significantly associated with an increased risk of 
127 mortality (Figure 1 and Figure 2). One risk factor (smoking) was associated with a 128 decreased risk of mortality (OR $0.52, \mathrm{Cl} 0.31-0.87$ ).

129 The risk of 30-day mortality among patients with one of any of the eight risk

130 factors was $50 \%$ higher compared to those with none of the eight risk factors (OR

$1311.5095 \% \mathrm{Cl} 1.08-2.07)$. The risk of 30 -day mortality increased as risk factors were

132 stacked, up to six risk factors (one: OR 1.50, Cl 1.08-2.07; two: OR 2.01, Cl 1.47-

133 2.75; three: OR 2.71, CI 1.99-3.69; four: OR 3.27, CI 2.39-4.47; five: OR 3.63, Cl

134 2.60-5.07; six: OR 4.23, $\mathrm{Cl}$ 2.69-6.65). The addition of each risk factor increased

135 the risk of 30 -day mortality by an average of $55 \%( \pm 13 \%$; median: $56 \%$,

136 interquartile range $51 \%-60 \%$ ), with the greatest increase between two and three

137 stacked risk factors (70\%). There were no statistically significant odds ratios

138 among patients with seven (OR 1.65, Cl 0.36-7.52) or eight (OR 2.14, Cl 0.25-

139 18.71) risk factors.

$140 \quad$ Among the 89 significant stacked risks, age was the most common risk

141 factor present $(50 / 89 ; 56.2 \%)$, followed by IC $(49 / 89,55.1 \%)$, CRD $(48 / 89,53.9 \%)$,

$142 \mathrm{CHD}(45 / 89,50.6 \%)$, CLD and smoking (both 37/89, 41.6\%), DM (32/89, 36\%),

143 and alcohol abuse $(29 / 89,32.6 \%)$. All risk factors were present at least once in

144 significant two, three, four, five, and six stacked risks with the exception of

145 smoking, which was not present in any two risk-factor combinations. Figure 3

146 shows the distribution of each risk factor according to the number of risk factors

147 present.

148 Of all significant individual risk factors, immunodeficiency was the strongest

149 predictor of 30-day mortality (OR 2.30, Cl 1.47-3.58). Among stacked risks, 
150 alcoholism + CLD (OR 6.20, 3.25-11.92), Age + CLD + IC (OR 42.90, Cl 4.69-

151 390.98), alcoholism + CLD + DM + IC (OR 32.10, Cl 3.28-314.3), age + CLD +

152 CRD + IC + smoking (OR 16.07, Cl 2.62-98.5), and Age + Alcoholism + CLD +

153 CRD + IC + smoking (OR 21.40, Cl 1.91-240.56) were the strongest predictors of

154 mortality for those with two, three, four, five, or six risk factors, respectively (Figure

155 2). Results for all stacked risks are available in Appendix $A$.

157 Discussion

158 We quantified the impact of stacking pneumococcal disease risk factors on

159 30-day mortality in unvaccinated older Veterans with serious pneumococcal

160 infections. Of the 8 individual risk factors assessed, $37.5 \%$ of them significantly

161 increased the risk of death and of the 247 stacked risks, $35 \%$ significantly

162 increased the risk of death. Current literature regarding predictors of mortality in

163 the setting of pneumococcal disease is primarily related to the impact of individual

164 predictors, particularly in the immunocompromised population, as well as those

165 with invasive pneumococcal disease.[8-16] However, there is a dearth of

166 information regarding outcomes of patients with multiple risk factors for

167 pneumococcal disease and the subsequent impact of this risk stacking. To our

168 knowledge, this study is the first to analyze the effect of risk factor combinations

169 on mortality. As the current body of literature strongly supports the association

170 between vaccination preventing invasive infections and subsequent mortality in the

171 setting of individual risk factors, the importance of disease prevention in patients

172 with multiple risk factors cannot be overstated.[1-3, 8, 10, 16] 
173 Mortality increased in each phase of risk stacking, up to six risk factors.

174 Compared to patients with none of the eight risk factors for the development of

175 pneumococcal disease, those with two risk factors were twice as likely to die at 30

176 days. Those with six risk factors were more than four times as likely to die

177 compared to those with no risk factors, and almost three times more likely to die

178 as those with a single risk factor. No seven or eight risk factor combinations were

179 statistically significant. However, this is likely due to smaller sample sizes in the

180 seven $(n=16)$ and eight $(n=6)$ stacked risk groups. As pointed out in a recent risk

181 stacking study, combining the effects of two independent risk factors as odds ratios

182 leads to a multiplicative effect, as odds ratios are calculated on a log scale.[5, 17]

183 Risk factors that are not entirely independent, however, may not be multiplicative.

184 Several risk factors we analyzed may often be seen together, including alcohol

185 abuse and liver disease, as well as smoking and respiratory and/or heart disease.

186 Our results demonstrated that as the odds ratio increased as risk factors were

187 stacked. However, the increased risk was not multiplicative, as would be expected

188 in the presence of related conditions.

189 Interestingly, smoking was associated with a lower risk of mortality in our

190 study. However, it should be noted that these were also individuals without any of

191 the other risk factors for pneumococcal disease, including heart disease or

192 respiratory disease, which are well-established consequences of smoking and also

193 contribute to mortality. Furthermore, we were unable to quantify the degree to

194 which individuals smoked. To be considered a smoker, documentation of smoking

195 cessation counseling, use of smoking cessation medication, or an ICD-9 diagnosis 
196 code within one year were necessary. As such, these patients may not have been

197 smokers at the time of infection. Collectively, these caveats require that the

198 association between smoking and risk of mortality within our study be interpreted

199 with caution.

200 The results of our study demonstrate the impact of increasing numbers of

201 pneumococcal disease risk factors on mortality among patients with serious

202 pneumococcal infections. Once individuals develop a pneumococcal infection,

203 there is a lasting negative impact. A recent study within the Veteran population

204 found that patients with pneumococcal pneumonia who survived at least 30 days

205 beyond infection had increased mortality compared to the expected survival for the

206 average Veteran with similar demographics for up to ten years after recovering

207 from the infection.[18] Furthermore, decreases in survival at ten years ranged from

$20815 \%$ to $50 \%$ according to increases in pneumonia severity index (PSI), which

209 accounts for risk factors also assessed in our study, including age, cardiac

210 disease, and hepatic dysfunction.[18, 19] As such, disease prevention may have

211 an extended positive impact on mortality.

212 Pneumococcal vaccination may be particularly important in patients with

213 multiple risk factors for pneumococcal disease. While the ACIP already

214 recommends that individuals with the risk factors assessed in our study be

215 vaccinated to prevent the development of pneumococcal disease, many adults

216 remain unvaccinated. $[1,3]$ This may be due, in part, to a lack of a focused strategy

217 for identifying those most at risk for poor outcomes. A study of 1,177 patients who

218 developed invasive pneumococcal disease and also had an indication for the 
219 polysaccharide pneumococcal vaccination demonstrated that $52 \%$ were

220 unvaccinated, and that $92 \%$ of these unvaccinated individuals had at least one

221 opportunity to receive the vaccination in the 2 years prior to infection. Multivariate

222 analysis revealed that alcohol abuse, metastatic malignancy, and those $\geq 65$ years

223 of age with no other indication were predictive of being unvaccinated, while

224 chemotherapy and non-HIV immune dysfunction were predictive of previous

225 vaccination.[20]

226 According to current ACIP pneumococcal vaccination recommendations,

227 patients in our study with cardiac, respiratory, and hepatic disease, along with

228 those who smoke, and have diabetes mellitus or alcoholism would have been

229 eligible to receive the 23-valent, pneumococcal polysaccharide vaccine (PPSV-

230 23). In addition, those 65 years of age and older, and those with

231 immunocompromising conditions are recommended to receive both the PPSV-23

232 and the 13-valent, pneumococcal conjugate vaccine (PCV-13). [3, 21] Further, all

233 children 6 weeks and older are currently recommended to receive PCV-13 (PCV-

2347 during our study period), thereby impacting development of pneumococcal

235 disease at the population level through herd immunity.[22, 23] In the general

236 population, pneumococcal vaccination, particularly with the conjugate vaccines,

237 has been associated with substantial reductions in disease incidence through

238 indirect protection.[23] However, the impact of herd immunity in the older Veteran

239 population remains unclear, and further studies are needed to determine if these

240 findings are consistent in this high-risk population. 
Considering that each additional risk factor in our study increased the risk

242 of mortality by $55 \%$ in the presence of pneumococcal disease, thorough evaluation

243 of a patient's medical history must be performed to ensure that, barring any 244 contraindications, all individuals with these risk factors are vaccinated.

245 Furthermore, it is important to note that the greatest increase between stacked

246 combinations occurred as patients went from two to three risk factors. Interestingly,

247 our findings are consistent with two other risk stacking studies assessing the risk

248 of developing pneumococcal disease, which showed that the greatest increase in

249 the risk of disease development occurred when increasing from two to three

250 disease states present.[6,21] Increases in disease development ranged from $67 \%$

251 to $265 \%$ moving from two to three disease states across all age ranges.[6, 24] As

252 such, our study provides further evidence that risk stacking poses a substantial

253 threat in older adults, in whom multiple, chronic disease states are common.[1, 6,

254 25] Furthermore, the results of our study may assist future efforts to increase

255 pneumococcal vaccination by providing healthcare practitioners with an estimate

256 of the quantified risk of mortality for patients with different combinations of risk

257 factors for developing pneumococcal disease.

258 Limitations of our study included the assessment of risk factors identified by

259 ACIP as necessitating pneumococcal vaccination. However, there may be other

260 conditions, or combinations of conditions, that collectively increase the risk of

261 mortality in the setting of pneumococcal disease which were not assessed in our

262 study. We utilized ICD-9 diagnosis to identify disease states, allowing for the

263 possibility of misclassification bias due to potential inaccuracies. Also, our study 
264 likely underestimated the true number of patients with pneumococcal pneumonia,

265 as we only included patients with a positive sputum culture and ICD-9 diagnosis

266 code. Further, pneumococcal pneumonia may have been the source for some

267 pneumococcal bacteremias, but without positive respiratory cultures, was not

268 categorized as such Next, patients with multiple episodes of pneumococcal

269 infection that were included in the study multiple times may have had a different

270 risk profile than those with a single episode of infection. However, this impact is

271 likely negligible, as the vast majority of patients only had one episode of infection

$272(9,730$ infections in 9,468 patients). Determining the risk of mortality in patients

273 with more than six stacked risk factors was limited by small sample sizes within

274 these groups. However, we believe the risk of mortality to likely be much higher

275 than healthy individuals, as mortality increased in stacked risk factor groups with

276 larger numbers. Next, as odds ratios only approximate relative risk, actual mortality

277 risk may differ. It should also be noted that our analysis did not specifically adjust

278 for pneumonia disease severity, such as with the Pneumonia Severity Index score.

279 However, given that many of the risk factors included in our study are also part of

280 this severity index, it is likely that pneumococcal disease severity also increased

281 with the number of stacked risks. [26] Lastly, as we studied an older Veteran

282 population, generalizability to the U.S. population as a whole is limited. 
In unvaccinated older Veterans with serious pneumococcal disease, the 287 presence of multiple ACIP risk factors for developing pneumococcal disease was 288 associated with higher 30-day all-cause mortality. The more indications for 289 vaccination present, the greater the risk of death, which was almost three times 290 higher among those with six stacked risk factors as opposed to a single risk factor.

291 As multiple risk factors for pneumococcal disease are common among older 292 adults, effective vaccination strategies for the prevention of infection are needed.

294 Acknowledgement: The views expressed are those of the authors and do not 295 necessarily reflect the position or policy of the United States Department of

296 Veterans Affairs. This material is based upon work supported, in part, by the Office

297 of Research and Development, Department of Veterans Affairs. JBM was 298 supported by Office of Academic Affiliations, Department of Veterans Affairs, and 299 HJM is supported in part by a VA New England Career Development Award.

301 Funding: This study was supported, in part, by an Advancing Science through 302 Pfizer Initiated Research (ASPIRE) grant from Pfizer Inc.

304 Conflict of Interest: Jacob Morton has no reported financial relationships

305 relevant to this article. Haley Morrill has received research funding from Merck.

306 Kerry LaPlante has received research funding and/or served as a scientific

307 advisor or consultant for Merck (Cubist), BARD/Davol, Allergan (Forest

308 Laboratories and Durata Therapeutics), The Medicines Company, and Pfizer Inc. 
309 Aisling Caffrey has received research funding from Pfizer Inc, Merck (Cubist),

310 and The Medicines Company.

311

312

313 


\section{References}

315 1. Morrill HJ, Caffrey AR, Noh E, LaPlante KL. Epidemiology of

316 pneumococcal disease in a national cohort of older adults. Infect Dis Ther.

$317 \quad 2014 ; 3(1): 19-33$.

318 2. Janoff EN, Musher DM. Streptococcus pneumoniae. In: Bennett JE, Dolin

319 R, Blaser MJ. Mandell, Douglas, and Bennett's Principles and Practice of

320 Infectious Diseases. 8 ed: Elsevier, 2015:2310-27.

321 3. Centers for Disease Control and Prevention. Use of 13-Valent

322 Pneumococcal Conjugate Vaccine and 23-Valent Pneumococcal

323 Polysaccharide Vaccine Among Adults Aged $\geq 65$ Years:

324 Recommendations of the Advisory Committee on Immunization Practices

325 (ACIP). MMWR Morb Mort Wkly Rep. 2014; (63):822-5.

326 4. World Health Organization. Pneumococcal vaccines WHO position paper.

$327 \quad$ Weekly Epidemiological Record. 2012; 87(14):129-44.

328 5. Curcio D, Cane A, Isturiz R. Redefining risk categories for pneumococcal

329 disease in adults: critical analysis of the evidence. Int J Infect Dis. 2015;

$330 \quad 37: 30-5$

331 6. Pelton SI, Shea KM, Weycker D, Farkouh RA, Strutton DR, Edelsberg J.

332 Rethinking risk for pneumococcal disease in adults: the role of risk

333 stacking. Open Forum Infect Dis. 2015; 2(1):ofv020.

334 7. Shea KM, Edelsberg J, Weycker D, Farkouh RA, Strutton DR, Pelton SI.

335 Rates of pneumococcal disease in adults with chronic medical conditions.

336 Open Forum Infect Dis. 2014; 1(1):ofu024. 
337 8. van de Beek D, de Gans J, Spanjaard L, Weisfelt M, Reitsma JB,

$338 \quad$ Vermeulen M. Clinical features and prognostic factors in adults with

339 bacterial meningitis. N Engl J Med. 2004; 351(18):1849-59.

340 9. Kalin M, Ortqvist A, Almela M, et al. Prospective study of prognostic

341 factors in community-acquired bacteremic pneumococcal disease in 5

$342 \quad$ countries. J Infect Dis. 2000; 182(3):840-7.

343 10. Hanada S, Iwata S, Kishi K, et al. Host Factors and Biomarkers

344 Associated with Poor Outcomes in Adults with Invasive Pneumococcal

$345 \quad$ Disease. PLoS One. 2016; 11(1):e0147877.

346 11. Chi RC, Jackson LA, Neuzil KM. Characteristics and outcomes of older

347 adults with community-acquired pneumococcal bacteremia. J Am Geriatr

$348 \quad$ Soc. $2006 ; 54(1): 115-20$.

349 12. Rudnick W, Liu Z, Shigayeva A, et al. Pneumococcal vaccination

350 programs and the burden of invasive pneumococcal disease in Ontario,

351 Canada, 1995-2011. Vaccine. 2013; 31(49):5863-71.

352 13. Lin SH, Liao WH, Lai CC, et al. Comparison of clinical features,

353 antimicrobial susceptibility, serotype distribution and outcomes of patients

354 with hospital- and community-associated invasive pneumococcal disease.

355 Int J Antimicrob Agents. 2010; 36(2):119-23.

356 14. Turett GS, Blum S, Fazal BA, Justman JE, Telzak EE. Penicillin resistance

357 and other predictors of mortality in pneumococcal bacteremia in a

358 population with high human immunodeficiency virus seroprevalence. Clin

$359 \quad$ Infect Dis. 1999; 29(2):321-7. 
360 15. Kumashi P, Girgawy E, Tarrand JJ, Rolston KV, Raad, II, Safdar A. Streptococcus pneumoniae bacteremia in patients with cancer: disease characteristics and outcomes in the era of escalating drug resistance (1998-2002). Medicine. 2005; 84(5):303-12.

364 16. Shigayeva A, Rudnick W, Green K, et al. Invasive Pneumococcal Disease

365 Among Immunocompromised Persons: Implications for Vaccination

366 Programs. Clin Infect Dis. 2016; 62(2):139-47.

367 17. Campbell MJ. Teaching logistic regression. International Association for

368 Statistical Education Conference Proceedings, ICOT 5. 1998.

369 18. Sandvall B, Rueda AM, Musher DM. Long-term survival following

370 pneumococcal pneumonia. Clin Infect Dis. 2013; 56(8):1145-6.

371 19. Aujesky D, Fine MJ. The pneumonia severity index: a decade after the

372 initial derivation and validation. Clin Infect Dis. 2008; 47 Suppl 3:S133-9.

373 20. Kyaw MH, Greene CM, Schaffner W, et al. Adults with invasive

374 pneumococcal disease: missed opportunities for vaccination. Am J Prev

$375 \quad$ Med. 2006; 31(4):286-92.

376 21. Centers for Disease Control and Prevention. Use of 13-valent pneumococcal conjugate vaccine and 23-valent pneumococcal

378 polysaccharide vaccine for adults with immunocompromising conditions:

379 recommendations of the Advisory Committee on Immunization Practices.

380 MMWR Morb Mort Wkly Rep. 2012; 61(40): 816-819.

381 22. Centers for Disease Control and Prevention. Prevention of pneumococcal 382 disease among infants and children - use of 13-valent pneumococcal 
conjugate vaccine and 23-valent pneumococcal polysaccharide vaccine: recommendations of the Advisory Committee on Immunization Practices. MMWR Morb Mort Wkly Rep. 2010; 59(RR11): 1-18.

386 23. Fine P, Eames K, Heymann DL. "Herd immunity": a rough guide. Clin Infect Dis. 2011; 52: 911-6.

388 24. Pelton SI, Shea KM, Farkouh RA, et al. Rates of pneumonia among children and adults with chronic medical conditions in Germany. BMC $390 \quad$ Infect Dis. 2015; 15:470.

391 25. Centers for Disease Control and Prevention. CDC National Health Report: 392 Leading Causes of Morbidity and Mortality and Associated Behavioral Risk and Protectie Factors-United States, 2005-2013. Morbidity and Mortality Weekly Report. 2014; 63(4).

395 26. Fine MJ, Auble TF, Yealy DM, Hanusa BH, Weissfeld LA, Singer DE, et al. 396 A prediction rule to identify low-risk patients with community-acquired pneumonia. N Engl J Med. 1997; 336(4):243-50. 
Table 1. Demographics of unvaccinated older adults with pneumococcal disease.

\begin{tabular}{|l|c|c|}
\hline & $\begin{array}{c}\text { Alive at 30 } \\
\text { days } \\
(\mathbf{n = 7 , 9 6 6 )}\end{array}$ & $\begin{array}{c}\text { Not alive at 30 } \\
\text { days } \\
(\mathbf{n = 1 , 7 6 4 )}\end{array}$ \\
\hline Age (years), (SD) & $67( \pm 11)$ & $71( \pm 11)^{\star}$ \\
\hline Gender, Male & $7,795(97.5)$ & $1,740(98.6)^{\star}$ \\
\hline Race & $98(1.2)$ & $14(0.8)$ \\
\hline American Indian & $63(0.8)$ & $11(0.6)$ \\
\hline Asian or Pacific Islander & $1,054(13.2)$ & $238(13.5)$ \\
\hline Black & $6,297(79.0)$ & $1,354(76.8)^{\star}$ \\
\hline White & $454(5.7)$ & $147(8.3)^{*}$ \\
\hline Unknown & & \\
\hline Pneumococcal Disease Risk & & \\
\hline Factors within previous year & $1,261(15.8)$ & $313(17.7)^{\star}$ \\
\hline Alcohol abuse & $1,999(25.1)$ & $611(34.6)^{*}$ \\
\hline Chronic heart disease & $1,324(16.6)$ & $489(27.7)^{*}$ \\
\hline Chronic heart failure & $705(8.9)$ & $320(18.1)^{*}$ \\
\hline Chronic liver disease, any & & \\
\hline severity & $3,609(45.3)$ & $911(51.6)^{*}$ \\
\hline Chronic respiratory disease & $1,709(21.5)$ & $476(27.0)^{*}$ \\
\hline Diabetes mellitus & $2,535(31.8)$ & $747(42.3)^{\star}$ \\
\hline Immunodeficiency & $3,777(47.4)$ & $674(38.2)^{*}$ \\
\hline Cigarette smoking &
\end{tabular}

Note: Results reported as $\mathrm{n}(\%)$ unless otherwise specified

${ }^{*} p<0.05$ 
Figure 1. Risk of 30-day mortality in unvaccinated adults with one pneumococcal disease risk factor.

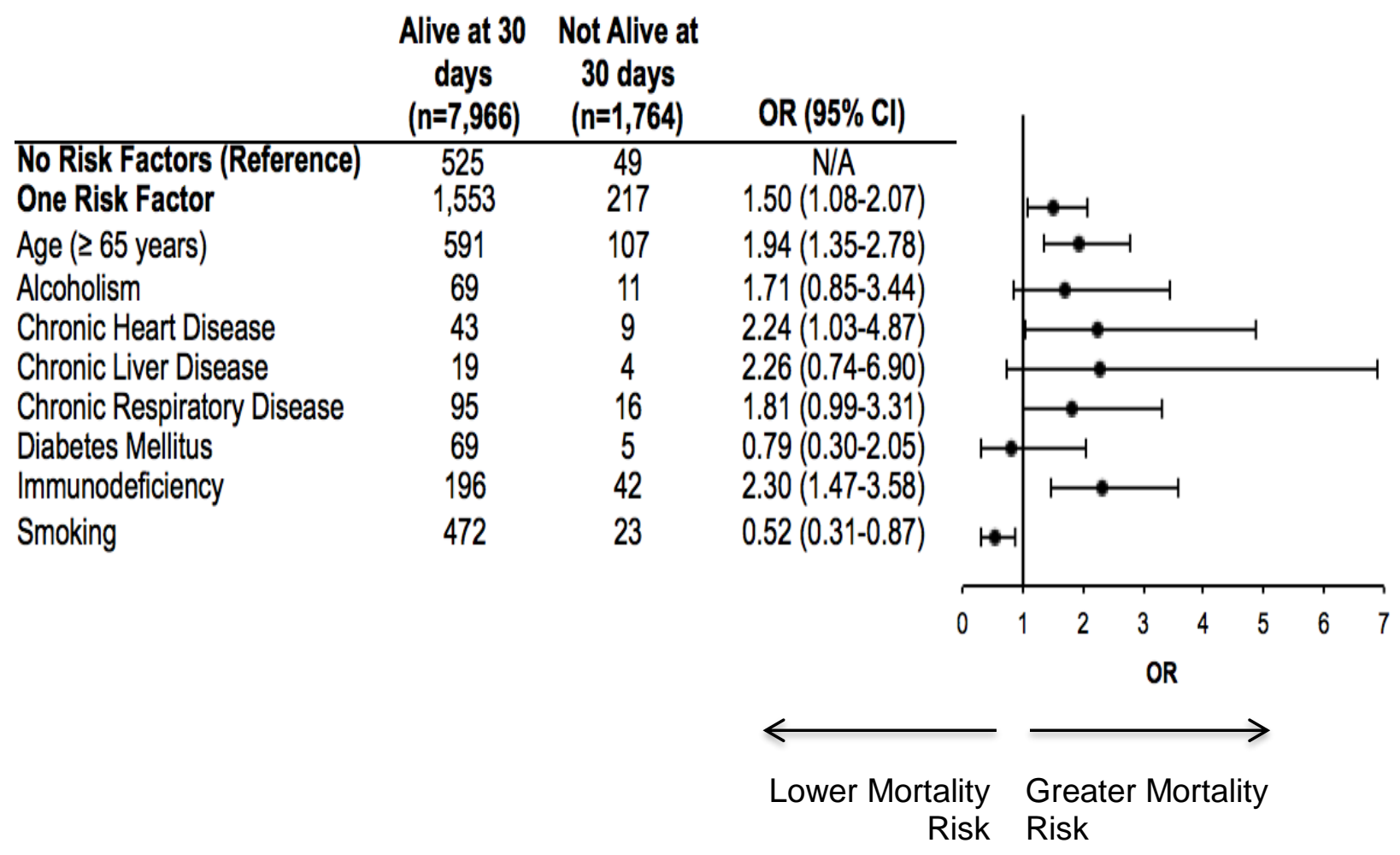

$\mathrm{Cl}$, Confidence Interval; OR, Odds Ratio 
Figure 2. Risk of 30-day mortality in unvaccinated adults with multiple pneumococcal disease risk factors. 


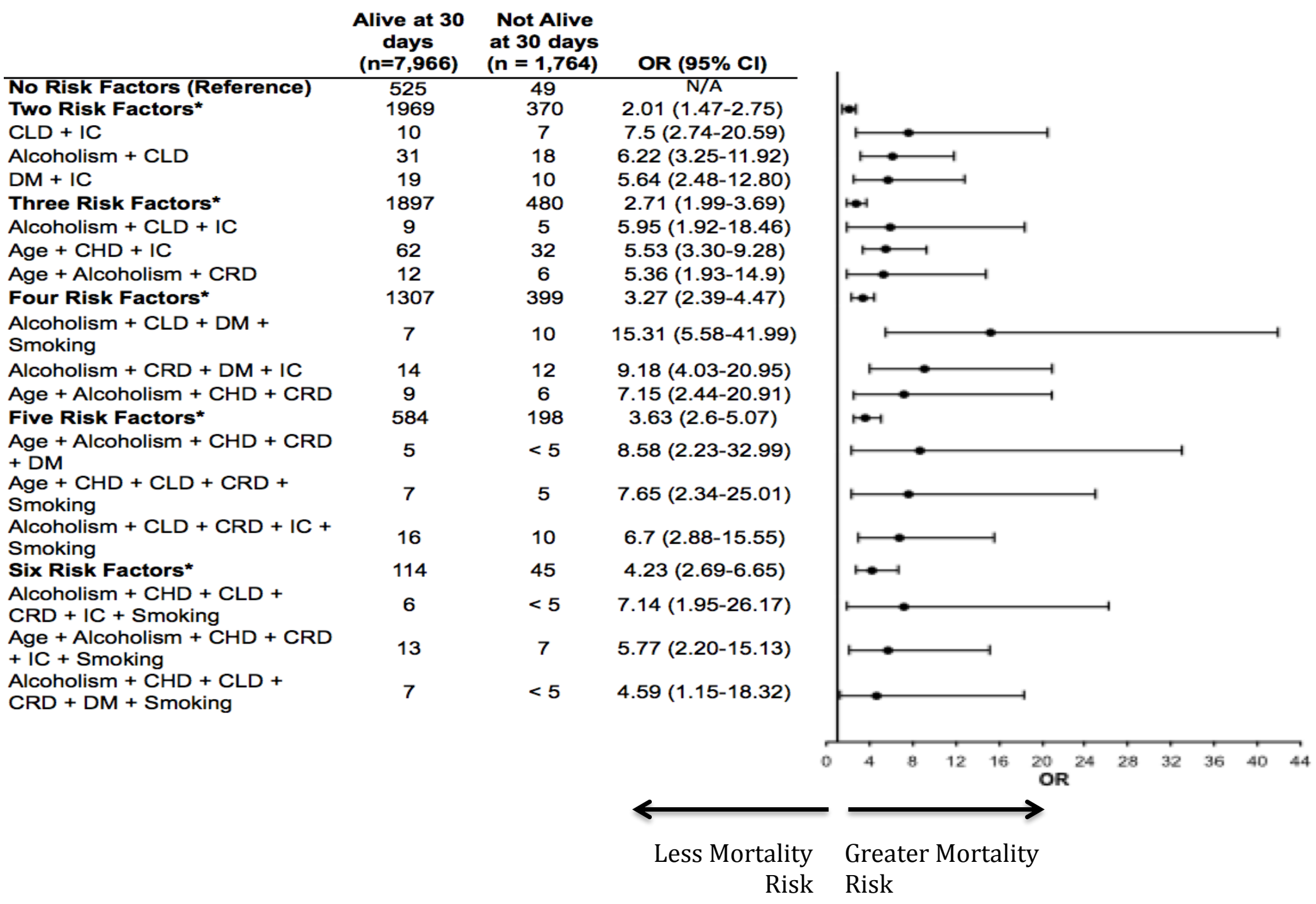


Age, Age $\geq 65$ years; CHD, Chronic heart disease; Cl, Confidence Interval; CLD, Chronic liver disease; CRD, Chronic respiratory disease; DM, Diabetes mellitus; IC, Immunodeficiency; OR, Odds Ratio

*Includes 3 selected statistically significant $\mathrm{OR}(\mathrm{Cl}$ does not contain 1) from each numerical category of risk factors present. No statistically significant seven or eight risk factor combinations. See supplemental appendix for risk for all unique combinations. 
Figure 3. Frequency of stacked pneumococcal disease risk factors in unvaccinated adults.

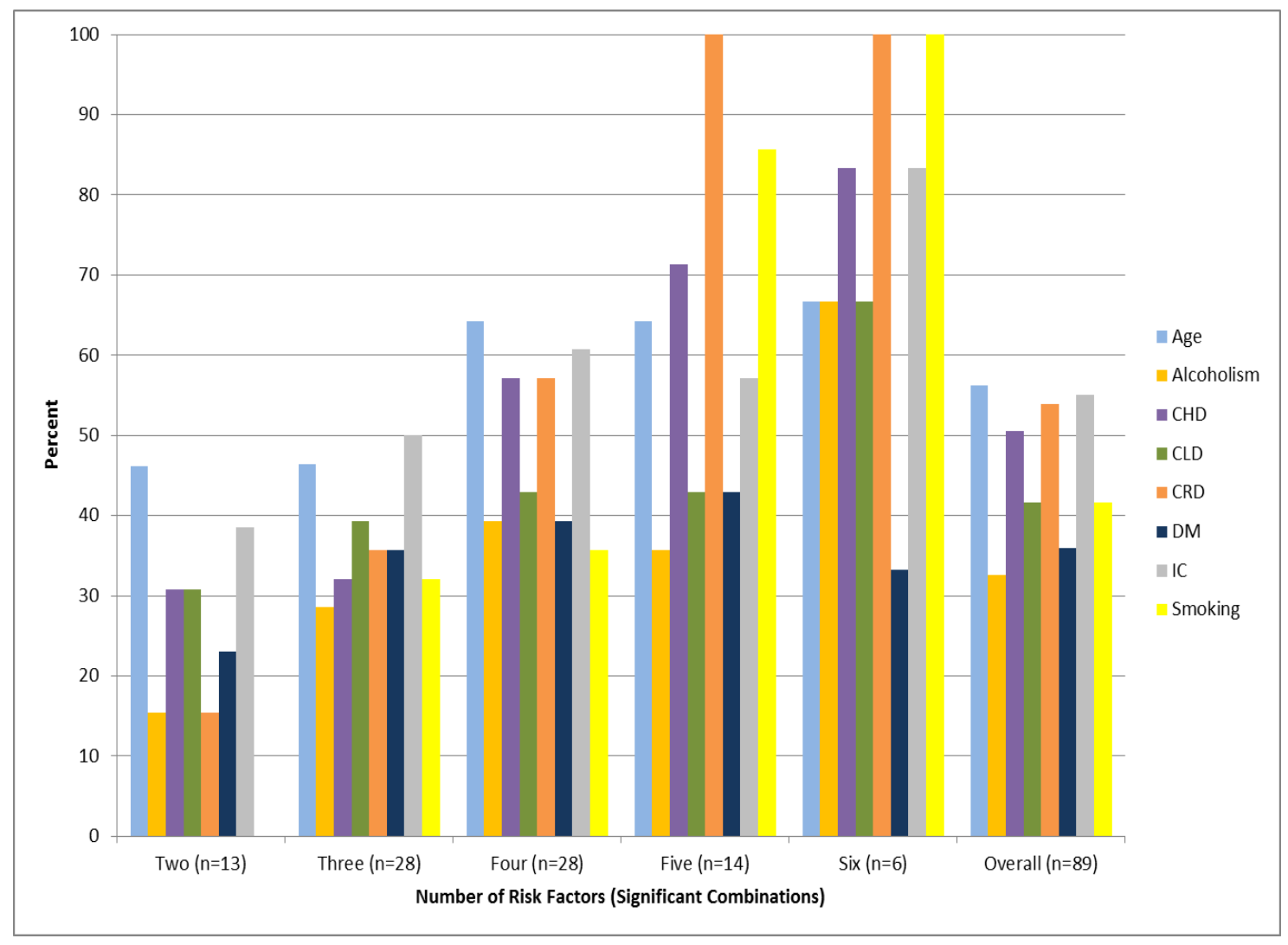

Age, Age $\geq 65$ years; CHD, Chronic Heart Disease; CLD, Chronic Liver Disease; CRD, Chronic Respiratory Disease; DM, Diabetes Mellitus; IC, Immunodeficiency Includes only stacked risk combinations which significantly increased the risk of 30-day mortality $(p<0.05)$. No statistically significant seven or eight risk factor combinations. 
Appendix A. Risk of 30-day mortality for all combinations of risk factors for developing pneumococcal disease.

\begin{tabular}{|c|c|c|c|c|}
\hline & $\begin{array}{c}\text { Alive at } \\
30 \text { days } \\
(n=7,966)\end{array}$ & $\begin{array}{c}\text { Not alive } \\
\text { at } 30 \\
\text { days } \\
(n=1,764)\end{array}$ & $\mathrm{OR}^{\mathrm{a}}$ & $95 \% \mathrm{Cl}$ \\
\hline No Risk factors & $525(6.6)$ & $49(2.8)$ & Reference & Reference \\
\hline Two Risk factors & $\begin{array}{r}1,969 \\
(24.7)\end{array}$ & $\begin{array}{c}370 \\
(21.0)\end{array}$ & 2.01 & $1.47-2.75^{\star}$ \\
\hline Age + Alcoholism & $22(0.3)$ & $9(0.5)$ & 4.38 & $1.91-10.04^{*}$ \\
\hline $\mathrm{Age}+\mathrm{CHD}$ & $111(1.4)$ & $51(2.9)$ & 4.92 & $3.16-7.66^{*}$ \\
\hline Age + CLD & $<5$ & $<5$ & 16.07 & $2.62-98.49^{*}$ \\
\hline Age + CRD & $262(3.3)$ & $57(3.2)$ & 2.33 & $1.55-3.51^{*}$ \\
\hline Age + DM & $75(0.9)$ & $29(1.6)$ & 4.14 & $2.47-6.96^{*}$ \\
\hline Age + IC & $323(4.1)$ & $56(3.2)$ & 1.86 & $1.24-2.79^{*}$ \\
\hline Age + Smoking & $217(2.7)$ & $16(0.9)$ & 0.79 & $0.44-1.42$ \\
\hline Alcoholism + CHD & $6(0.08)$ & $<5$ & 1.79 & $0.21-15.13$ \\
\hline Alcoholism + CLD & $31(0.4)$ & $18(1.0)$ & 6.22 & $3.25-11.92^{*}$ \\
\hline Alcoholism + CRD & $24(0.3)$ & $<5$ & 1.34 & $0.39-4.61$ \\
\hline Alcoholism + DM & $<5$ & 0 & $\mathrm{n} / \mathrm{a}$ & $\mathrm{n} / \mathrm{a}$ \\
\hline Alcoholism + IC & $14(0.2)$ & 0 & $\mathrm{n} / \mathrm{a}$ & $\mathrm{n} / \mathrm{a}$ \\
\hline Alcoholism + Smoking & $141(1.8)$ & $14(0.8)$ & 1.06 & $0.57-1.98$ \\
\hline $\mathrm{CHD}+\mathrm{CLD}$ & $<5$ & $<5$ & 10.71 & $1.48-77.69^{*}$ \\
\hline $\mathrm{CHD}+\mathrm{CRD}$ & $32(0.4)$ & $6(0.3)$ & 2.01 & $0.80-5.04$ \\
\hline $\mathrm{CHD}+\mathrm{DM}$ & $33(0.4)$ & $11(0.6)$ & 3.57 & $1.70-7.50^{*}$ \\
\hline $\mathrm{CHD}+\mathrm{IC}$ & $18(0.2)$ & $10(0.6)$ & 5.95 & $2.60-13.60^{*}$ \\
\hline CHD + Smoking & $48(0.6)$ & $<5$ & 0.67 & $0.20-2.23$ \\
\hline CLD + CRD & $6(0.08)$ & $<5$ & 1.79 & $0.21-15.13$ \\
\hline CLD + DM & $9(0.1)$ & $<5$ & 1.19 & $0.15-9.59$ \\
\hline CLD + IC & $10(0.1)$ & $7(0.4)$ & 7.50 & $2.74-20.59^{*}$ \\
\hline CLD + Smoking & $27(0.3)$ & $<5$ & 0.79 & $0.18-3.44$ \\
\hline CRD + DM & $24(0.3)$ & $<5$ & 0.45 & $0.06-3.37$ \\
\hline CRD + IC & $35(0.4)$ & $14(0.8)$ & 4.23 & $2.16-8.51^{*}$ \\
\hline CRD + Smoking & $224(2.8)$ & $13(0.7)$ & 0.62 & $0.33-1.17$ \\
\hline $\mathrm{DM}+\mathrm{IC}$ & $19(0.2)$ & $10(0.6)$ & 5.64 & $2.48-12.80^{*}$ \\
\hline DM + Smoking & $54(0.7)$ & $5(0.3)$ & 0.99 & $0.38-2.60$ \\
\hline $\mathrm{IC}+$ Smoking & $197(2.5)$ & $27(1.5)$ & 1.47 & $0.89-2.42$ \\
\hline Three Risk factors & $\begin{array}{l}1,897 \\
(23.8)\end{array}$ & $\begin{array}{c}480 \\
(27.2)\end{array}$ & 2.71 & $1.99-3.69^{*}$ \\
\hline Age + Alcoholism + CHD & $5(0.06)$ & $<5$ & 2.14 & $0.25-18.71$ \\
\hline
\end{tabular}




\begin{tabular}{|c|c|c|c|c|}
\hline Age + Alcoholism + CLD & $5(0.06)$ & $<5$ & 2.14 & $0.25-18.71$ \\
\hline Age + Alcoholism + CRD & $12(0.2)$ & $6(0.3)$ & 5.36 & 1.93-14.90* \\
\hline Age + Alcoholism + DM & $<5$ & 0 & $\mathrm{n} / \mathrm{a}$ & $\mathrm{n} / \mathrm{a}$ \\
\hline Age + Alcoholism + IC & $5(0.06)$ & $<5$ & 6.43 & $1.49-27.7^{*}$ \\
\hline Age + Alcoholism + Smoking & $25(0.3)$ & $<5$ & 0.86 & $0.19-3.73$ \\
\hline $\mathrm{Age}+\mathrm{CHD}+\mathrm{CLD}$ & $<5$ & $<5$ & 5.36 & $0.96-29.99$ \\
\hline $\mathrm{Age}+\mathrm{CHD}+\mathrm{CRD}$ & $249(3.1)$ & $90(5.1)$ & 3.87 & $2.65-5.66^{*}$ \\
\hline $\mathrm{Age}+\mathrm{CHD}+\mathrm{DM}$ & $110(1.4)$ & $41(2.3)$ & 3.99 & $2.51-6.35^{\star}$ \\
\hline $\mathrm{Age}+\mathrm{CHD}+\mathrm{IC}$ & $62(0.8)$ & $32(1.8)$ & 5.53 & $3.30-9.28^{*}$ \\
\hline Age + CHD + Smoking & $28(0.4)$ & $9(0.5)$ & 3.44 & $1.54-7.71^{*}$ \\
\hline Age + CLD + CRD & $<5$ & $<5$ & 32.10 & $3.28-314.30^{*}$ \\
\hline Age + CLD + DM & $<5$ & $<5$ & 2.68 & $0.29-24.44$ \\
\hline $\mathrm{Age}+\mathrm{CLD}+\mathrm{IC}$ & $<5$ & $<5$ & 42.86 & $4.69-390.98^{*}$ \\
\hline Age + CLD + Smoking & $<5$ & $<5$ & 21.43 & $1.91-240.56^{*}$ \\
\hline Age + CRD + DM & $70(0.9)$ & $16(0.9)$ & 2.45 & $1.32-4.54^{*}$ \\
\hline $\mathrm{Age}+\mathrm{CRD}+\mathrm{IC}$ & $145(1.8)$ & $43(2.4)$ & 3.18 & $2.03-4.98^{*}$ \\
\hline Age + CRD + Smoking & $186(2.4)$ & $27(1.5)$ & 1.56 & $0.95-2.56$ \\
\hline$A g e+D M+I C$ & $38(0.5)$ & $14(0.8)$ & 3.95 & $2.00-7.79^{*}$ \\
\hline Age + DM + Smoking & $29(0.4)$ & $<5$ & 1.48 & $0.50-4.38$ \\
\hline Age + IC + Smoking & $123(1.5)$ & $24(1.4)$ & 2.09 & $1.24-3.54^{*}$ \\
\hline Alcoholism + CHD + CLD & $<5$ & $<5$ & 10.71 & $1.48-77.69^{\star}$ \\
\hline Alcoholism + CHD + CRD & $10(0.1)$ & $<5$ & 2.14 & $0.46-10.06$ \\
\hline Alcoholism + CHD + DM & $<5$ & $<5$ & 2.68 & $0.29-24.44$ \\
\hline Alcoholism + CHD + IC & $<5$ & 0 & $\mathrm{n} / \mathrm{a}$ & $\mathrm{n} / \mathrm{a}$ \\
\hline Alcoholism + CHD + Smoking & $21(0.3)$ & $<5$ & 1.02 & $0.23-4.48$ \\
\hline Alcoholism + CLD + CRD & $12(0.2)$ & $5(0.3)$ & 4.47 & $1.51-13.20^{*}$ \\
\hline Alcoholism + CLD + DM & $<5$ & $<5$ & 8.04 & $1.75-36.96^{*}$ \\
\hline Alcoholism + CLD + IC & $9(0.1)$ & $5(0.3)$ & 5.95 & $1.92-18.46^{*}$ \\
\hline Alcoholism + CLD + Smoking & $52(0.7)$ & $18(1.0)$ & 3.71 & $2.01-6.83^{*}$ \\
\hline Alcoholism + CRD + DM & 0 & 0 & $\mathrm{n} / \mathrm{a}$ & $\mathrm{n} / \mathrm{a}$ \\
\hline Alcoholism + CRD + IC & $7(0.09)$ & $<5$ & 3.06 & $0.62-15.14$ \\
\hline Alcoholism + CRD + Smoking & $128(1.6)$ & $5(0.3)$ & 0.42 & $0.16-1.07$ \\
\hline Alcoholism + DM + Smoking & 0 & 0 & $\mathrm{n} / \mathrm{a}$ & $\mathrm{n} / \mathrm{a}$ \\
\hline Alcoholism + DM + Smoking & $23(0.3)$ & $<5$ & 1.40 & $0.41-4.82$ \\
\hline Alcoholism + IC + Smoking & $40(0.5)$ & $13(0.7)$ & 3.48 & $1.75-6.95^{*}$ \\
\hline $\mathrm{CHD}+\mathrm{CLD}+\mathrm{CRD}$ & $<5$ & $<5$ & 2.68 & $0.29-24.44$ \\
\hline $\mathrm{CHD}+\mathrm{CLD}+\mathrm{DM}$ & $<5$ & $<5$ & 10.71 & $2.10-54.51^{*}$ \\
\hline $\mathrm{CHD}+\mathrm{CLD}+\mathrm{IC}$ & $<5$ & $<5$ & 5.36 & $0.48-60.14$ \\
\hline CHD + CLD + Smoking & $<5$ & $<5$ & 2.68 & $0.29-24.44$ \\
\hline $\mathrm{CHD}+\mathrm{CRD}+\mathrm{DM}$ & $51(0.6)$ & $9(0.5)$ & 1.89 & $0.88-4.07$ \\
\hline $\mathrm{CHD}+\mathrm{CRD}+\mathrm{IC}$ & $25(0.3)$ & $<5$ & 1.29 & $0.38-4.41$ \\
\hline
\end{tabular}




\begin{tabular}{|c|c|c|c|c|}
\hline $\mathrm{CHD}+\mathrm{CRD}+$ Smoking & $87(1.1)$ & $17(1.0)$ & 2.09 & $1.15-3.80^{*}$ \\
\hline$C H D+D M+I C$ & $13(0.2)$ & $4(0.2)$ & 3.30 & $1.04-10.50^{*}$ \\
\hline $\mathrm{CHD}+\mathrm{DM}+$ Smoking & $36(0.5)$ & $<5$ & 0.89 & $0.27-3.01$ \\
\hline $\mathrm{CHD}+\mathrm{IC}+$ Smoking & $15(0.2)$ & $5(0.3)$ & 3.57 & $1.25-10.24^{*}$ \\
\hline CLD + CRD + DM & $<5$ & $<5$ & 7.14 & $1.17-43.78^{\star}$ \\
\hline$C L D+C R D+I C$ & $6(0.08)$ & $<5$ & 1.79 & $0.21-15.13$ \\
\hline CLD + CRD + Smoking & $17(0.2)$ & $<5$ & 1.26 & $0.28-5.62$ \\
\hline$C L D+D M+I C$ & $<5$ & $<5$ & 7.14 & $1.17-43.78^{\star}$ \\
\hline CLD + DM + Smoking & $10(0.1)$ & 0 & $\mathrm{n} / \mathrm{a}$ & $\mathrm{n} / \mathrm{a}$ \\
\hline CLD + IC + Smoking & $17(0.2)$ & $<5$ & 2.52 & $0.82-7.79$ \\
\hline$C R D+D M+I C$ & $12(0.2)$ & $<5$ & 3.57 & $1.11-11.49^{\star}$ \\
\hline CRD + DM + Smoking & $50(0.6)$ & $<5$ & 0.43 & $0.10-1.82$ \\
\hline CRD + IC + Smoking & $101(1.3)$ & $23(1.3)$ & 2.44 & $1.42-4.18^{*}$ \\
\hline $\mathrm{DM}+\mathrm{IC}+$ Smoking & $19(0.2)$ & $7(0.4)$ & 3.95 & $1.58-9.85^{\star}$ \\
\hline Four Risk factors & $\begin{array}{l}1,307 \\
(16.5)\end{array}$ & $\begin{array}{c}399 \\
(22.6)\end{array}$ & 3.27 & $2.39-4.47^{*}$ \\
\hline Age + Alcoholism + CHD + CLD & $<5$ & $<5$ & 10.71 & $2.11-54.51^{*}$ \\
\hline $\begin{array}{l}\text { Age + Alcoholism + CHD + } \\
\text { CRD }\end{array}$ & $9(0.1)$ & $6(0.3)$ & 7.15 & $2.44-20.91^{*}$ \\
\hline Age + Alcoholism + CHD + DM & $<5$ & $<5$ & 3.57 & $0.37-34.99$ \\
\hline Age + Alcoholism + CHD + IC & 0 & $<5$ & $\mathrm{n} / \mathrm{a}$ & $\mathrm{n} / \mathrm{a}$ \\
\hline $\begin{array}{l}\text { Age + Alcoholism + CHD + } \\
\text { Smoking }\end{array}$ & $6(0.08)$ & $<5$ & 5.36 & $1.30-22.09^{*}$ \\
\hline Age + Alcoholism + CLD + CRD & $<5$ & $<5$ & 8.04 & $1.75-36.96^{*}$ \\
\hline Age + Alcoholism + CLD + DM & 0 & $<5$ & $\mathrm{n} / \mathrm{a}$ & $\mathrm{n} / \mathrm{a}$ \\
\hline Age + Alcoholism + CLD + IC & $<5$ & 0 & $\mathrm{n} / \mathrm{a}$ & $\mathrm{n} / \mathrm{a}$ \\
\hline $\begin{array}{l}\text { Age + Alcoholism + CLD + } \\
\text { Smoking }\end{array}$ & $<5$ & $<5$ & 2.68 & $0.29-24.44$ \\
\hline Age + Alcoholism + CRD + DM & $<5$ & $<5$ & 10.71 & $2.11-54.51^{*}$ \\
\hline Age + Alcoholism + CRD + IC & $8(0.1)$ & $<5$ & 4.02 & $1.03-15.64^{*}$ \\
\hline $\begin{array}{l}\text { Age + Alcoholism + CRD + } \\
\text { Smoking }\end{array}$ & $39(0.5)$ & $7(0.4)$ & 1.92 & $0.82-4.53$ \\
\hline Age + Alcoholism + DM + IC & $<5$ & 0 & $\mathrm{n} / \mathrm{a}$ & $\mathrm{n} / \mathrm{a}$ \\
\hline $\begin{array}{l}\text { Age + Alcoholism + DM + } \\
\text { Smoking }\end{array}$ & $<5$ & $<5$ & 10.71 & $0.66-173.96$ \\
\hline $\begin{array}{l}\text { Age + Alcoholism + IC + } \\
\text { Smoking }\end{array}$ & $9(0.1)$ & $<5$ & 2.38 & $0.50-11.33$ \\
\hline $\mathrm{Age}+\mathrm{CHD}+\mathrm{CLD}+\mathrm{CRD}$ & $<5$ & $<5$ & 21.43 & 1.91-240.56 \\
\hline $\mathrm{Age}+\mathrm{CHD}+\mathrm{CLD}+\mathrm{DM}$ & $<5$ & $<5$ & 10.71 & $2.60-44.17^{*}$ \\
\hline $\mathrm{Age}+\mathrm{CHD}+\mathrm{CLD}+\mathrm{IC}$ & $<5$ & $<5$ & 16.07 & $2.62-98.50^{*}$ \\
\hline Age + CHD + CLD + Smoking & $<5$ & $<5$ & 5.36 & $0.48-60.14$ \\
\hline $\mathrm{Age}+\mathrm{CHD}+\mathrm{CRD}+\mathrm{DM}$ & $172(2.2)$ & $56(3.2)$ & 3.49 & $2.29-5.31^{*}$ \\
\hline
\end{tabular}




\begin{tabular}{|c|c|c|c|c|}
\hline $\mathrm{Age}+\mathrm{CHD}+\mathrm{CRD}+\mathrm{IC}$ & $152(1.9)$ & $53(3.0)$ & 3.74 & $2.43-5.73^{*}$ \\
\hline $\mathrm{Age}+\mathrm{CHD}+\mathrm{CRD}+$ Smoking & $162(2.0)$ & $47(2.7)$ & 3.11 & $2.01-4.81^{*}$ \\
\hline $\mathrm{Age}+\mathrm{CHD}+\mathrm{DM}+\mathrm{IC}$ & $45(0.6)$ & $18(1.0)$ & 4.29 & $2.31-7.97^{*}$ \\
\hline Age + CHD + DM + Smoking & $24(0.3)$ & $5(0.3)$ & 2.23 & $0.82-6.11$ \\
\hline Age $+\mathrm{CHD}+\mathrm{IC}+$ Smoking & $24(0.3)$ & $8(0.5)$ & 3.57 & $1.52-8.37^{*}$ \\
\hline $\mathrm{Age}+\mathrm{CLD}+\mathrm{CRD}+\mathrm{DM}$ & $<5$ & 0 & $\mathrm{n} / \mathrm{a}$ & $\mathrm{n} / \mathrm{a}$ \\
\hline $\mathrm{Age}+\mathrm{CLD}+\mathrm{CRD}+\mathrm{IC}$ & $<5$ & $<5$ & 7.14 & $1.17-43.78^{*}$ \\
\hline Age + CLD + CRD + Smoking & $<5$ & 0 & $\mathrm{n} / \mathrm{a}$ & $\mathrm{n} / \mathrm{a}$ \\
\hline$A g e+C L D+D M+I C$ & $6(0.08)$ & 0 & $\mathrm{n} / \mathrm{a}$ & $\mathrm{n} / \mathrm{a}$ \\
\hline Age + CLD + DM + Smoking & $<5$ & 0 & $\mathrm{n} / \mathrm{a}$ & $\mathrm{n} / \mathrm{a}$ \\
\hline Age + CLD + IC + Smoking & $<5$ & $<5$ & 10.71 & $0.66-173.96$ \\
\hline Age + CRD + DM + IC & $44(0.6)$ & $9(0.5)$ & 2.19 & $1.01-4.76^{*}$ \\
\hline Age + CRD + DM + Smoking & $43(0.5)$ & $6(0.3)$ & 1.50 & $0.61-3.69$ \\
\hline Age + CRD + IC + Smoking & $120(1.5)$ & $36(2.0)$ & 3.22 & $2.00-5.16^{*}$ \\
\hline Age + DM + IC + Smoking & $15(0.2)$ & $6(0.3)$ & 4.29 & $1.59-11.55^{\star}$ \\
\hline $\begin{array}{l}\text { Alcoholism + CHD + CLD + } \\
\text { CRD }\end{array}$ & $5(0.06)$ & $<5$ & 4.29 & $0.81-22.68$ \\
\hline Alcoholism + CHD + CLD + DM & $<5$ & $<5$ & 3.57 & $0.37-34.99$ \\
\hline Alcoholism + CHD + CLD + IC & $<5$ & 0 & $\mathrm{n} / \mathrm{a}$ & $\mathrm{n} / \mathrm{a}$ \\
\hline $\begin{array}{l}\text { Alcoholism + CHD + CLD + } \\
\text { Smoking }\end{array}$ & 15 & $<5$ & 2.86 & $0.91-8.95$ \\
\hline Alcoholism + CHD + CRD + DM & $<5$ & 0 & $\mathrm{n} / \mathrm{a}$ & $\mathrm{n} / \mathrm{a}$ \\
\hline $\begin{array}{l}\text { Alcoholism + CHD + CRD + } \\
\text { Smoking }\end{array}$ & $57(0.7)$ & $<5$ & 0.38 & $0.09-1.59$ \\
\hline Alcoholism + CHD + DM + IC & 0 & $<5$ & $\mathrm{n} / \mathrm{a}$ & $\mathrm{n} / \mathrm{a}$ \\
\hline $\begin{array}{l}\text { Alcoholism + CHD + DM + } \\
\text { Smoking }\end{array}$ & $9(0.1)$ & 0 & $\mathrm{n} / \mathrm{a}$ & $\mathrm{n} / \mathrm{a}$ \\
\hline $\begin{array}{l}\text { Alcoholism + CHD + IC + } \\
\text { Smoking }\end{array}$ & $10(0.1)$ & $<5$ & 1.07 & $0.134-8.55$ \\
\hline Alcoholism + CLD + CRD + DM & $<5$ & $<5$ & 5.36 & $0.48-60.14$ \\
\hline Alcoholism + CLD + CRD + IC & $5(0.06)$ & $<5$ & 6.43 & $1.49-27.71^{*}$ \\
\hline $\begin{array}{l}\text { Alcoholism + CLD + CRD + } \\
\text { Smoking }\end{array}$ & $37(0.5)$ & $6(0.3)$ & 1.74 & $0.70-4.32$ \\
\hline Alcoholism + CLD + DM + IC & $<5$ & $<5$ & 32.10 & 3.28-314.30, \\
\hline $\begin{array}{l}\text { Alcoholism + CLD + DM + } \\
\text { Smoking }\end{array}$ & $7(0.1)$ & $10(0.6)$ & 15.31 & $5.58-41.99^{*}$ \\
\hline $\begin{array}{l}\text { Alcoholism + CLD + IC + } \\
\text { Smoking }\end{array}$ & $14(0.2)$ & $12(0.7)$ & 9.18 & $4.03-20.95^{\star}$ \\
\hline Alcoholism + CRD + DM + IC & $<5$ & 0 & $\mathrm{n} / \mathrm{a}$ & $\mathrm{n} / \mathrm{a}$ \\
\hline $\begin{array}{l}\text { Alcoholism + CRD + DM + } \\
\text { Smoking }\end{array}$ & $14(0.2)$ & $<5$ & 0.77 & $0.10-5.94$ \\
\hline $\begin{array}{l}\text { Alcoholism + CRD + IC + } \\
\text { Smoking }\end{array}$ & $40(0.5)$ & $13(0.7)$ & 3.48 & $1.75-6.95^{\star}$ \\
\hline
\end{tabular}




\begin{tabular}{|c|c|c|c|c|}
\hline $\begin{array}{l}\text { Alcoholism + DM + IC + } \\
\text { Smoking }\end{array}$ & $<5$ & $<5$ & 2.68 & $0.29-24.44$ \\
\hline $\mathrm{CHD}+\mathrm{CLD}+\mathrm{CRD}+\mathrm{DM}$ & $5(0.06)$ & $<5$ & 2.14 & $0.25-18.71$ \\
\hline $\mathrm{CHD}+\mathrm{CLD}+\mathrm{CRD}+\mathrm{IC}$ & $<5$ & $<5$ & 21.43 & $1.91-240.56^{\star}$ \\
\hline $\mathrm{CHD}+\mathrm{CLD}+\mathrm{CRD}+$ Smoking & $11(0.1)$ & $<5$ & 1.95 & $0.42-9.04$ \\
\hline $\mathrm{CHD}+\mathrm{CLD}+\mathrm{DM}+\mathrm{IC}$ & $<5$ & $<5$ & 10.71 & $1.48-77.69^{\star}$ \\
\hline $\mathrm{CHD}+\mathrm{CLD}+\mathrm{DM}+$ Smoking & $<5$ & 0 & $\mathrm{n} / \mathrm{a}$ & $\mathrm{n} / \mathrm{a}$ \\
\hline CHD + CLD + IC + Smoking & $<5$ & 0 & $\mathrm{n} / \mathrm{a}$ & $\mathrm{n} / \mathrm{a}$ \\
\hline $\mathrm{CHD}+\mathrm{CRD}+\mathrm{DM}+\mathrm{IC}$ & $13(0.2)$ & $7(0.4)$ & 5.77 & $2.20-15.13^{*}$ \\
\hline $\mathrm{CHD}+\mathrm{CRD}+\mathrm{DM}+$ Smoking & $53(0.7)$ & $17(1.0)$ & 3.44 & $1.85-6.39^{*}$ \\
\hline $\mathrm{CHD}+\mathrm{CRD}+\mathrm{IC}+$ Smoking & $38(0.5)$ & $13(0.7)$ & 3.67 & $1.83-7.34^{*}$ \\
\hline $\mathrm{CHD}+\mathrm{DM}+\mathrm{IC}+$ Smoking & $12(0.2)$ & 0 & $\mathrm{n} / \mathrm{a}$ & $\mathrm{n} / \mathrm{a}$ \\
\hline$C L D+C R D+D M+I C$ & $<5$ & $<5$ & 10.71 & $0.66-173.96$ \\
\hline CLD + CRD + DM + Smoking & $<5$ & 0 & $\mathrm{n} / \mathrm{a}$ & $\mathrm{n} / \mathrm{a}$ \\
\hline CLD + CRD + IC + Smoking & $9(0.1)$ & $<5$ & 2.38 & $0.50-11.33$ \\
\hline CLD + DM + IC + Smoking & $<5$ & 0 & $\mathrm{n} / \mathrm{a}$ & $\mathrm{n} / \mathrm{a}$ \\
\hline CRD + DM + IC + Smoking & $9(0.1)$ & $<5$ & 1.19 & $0.15-9.59$ \\
\hline Five Risk factors & $584(7.3)$ & $\begin{array}{r}198 \\
(11.2)\end{array}$ & 3.63 & $2.60-5.07^{*}$ \\
\hline $\begin{array}{l}\text { Age + Alcoholism + CHD + CLD } \\
+ \text { CRD }\end{array}$ & $5(0.06)$ & $<5$ & 4.29 & $0.81-22.68$ \\
\hline $\begin{array}{l}\text { Age + Alcoholism + CHD + CLD } \\
+ \text { DM }\end{array}$ & 0 & 0 & $\mathrm{n} / \mathrm{a}$ & $\mathrm{n} / \mathrm{a}$ \\
\hline $\begin{array}{l}\text { Age + Alcoholism + CHD + CLD } \\
+ \text { IC }\end{array}$ & 0 & 0 & $\mathrm{n} / \mathrm{a}$ & $\mathrm{n} / \mathrm{a}$ \\
\hline $\begin{array}{l}\text { Age + Alcoholism + CHD + CLD } \\
+ \text { Smoking }\end{array}$ & 0 & $<5$ & $\mathrm{n} / \mathrm{a}$ & $\mathrm{n} / \mathrm{a}$ \\
\hline $\begin{array}{l}\text { Age + Alcoholism + CHD + } \\
\text { CRD + DM }\end{array}$ & $5(0.06)$ & $<5$ & 8.58 & $2.23-32.99^{*}$ \\
\hline $\begin{array}{l}\text { Age + Alcoholism + CHD + } \\
\text { CRD + IC }\end{array}$ & $7(0.09)$ & $<5$ & 1.53 & $0.19-12.70$ \\
\hline $\begin{array}{l}\text { Age + Alcoholism + CHD + } \\
\text { CRD + Smoking }\end{array}$ & $29(0.4)$ & $11(0.6)$ & 4.06 & $1.91-8.63^{*}$ \\
\hline $\begin{array}{l}\text { Age + Alcoholism + CHD + DM } \\
+ \text { IC }\end{array}$ & $<5$ & 0 & $\mathrm{n} / \mathrm{a}$ & $\mathrm{n} / \mathrm{a}$ \\
\hline $\begin{array}{l}\text { Age + Alcoholism + CHD + DM } \\
+ \text { Smoking }\end{array}$ & $<5$ & 0 & $\mathrm{n} / \mathrm{a}$ & $\mathrm{n} / \mathrm{a}$ \\
\hline $\begin{array}{l}\text { Age + Alcoholism + CHD + IC + } \\
\text { Smoking }\end{array}$ & $5(0.06)$ & $<5$ & 4.29 & $0.81-22.68$ \\
\hline $\begin{array}{l}\text { Age + Alcoholism + CLD + CRD } \\
+ \text { DM }\end{array}$ & 0 & 0 & $\mathrm{n} / \mathrm{a}$ & $\mathrm{n} / \mathrm{a}$ \\
\hline
\end{tabular}




\begin{tabular}{|c|c|c|c|c|}
\hline $\begin{array}{l}\text { Age + Alcoholism + CLD + CRD } \\
+ \text { IC }\end{array}$ & $<5$ & $<5$ & 5.36 & $0.48-60.14$ \\
\hline $\begin{array}{l}\text { Age + Alcoholism + CLD + CRD } \\
+ \text { Smoking }\end{array}$ & $11(0.1)$ & 0 & $\mathrm{n} / \mathrm{a}$ & $\mathrm{n} / \mathrm{a}$ \\
\hline $\begin{array}{l}\text { Age + Alcoholism + CLD + DM } \\
+ \text { IC }\end{array}$ & $<5$ & 0 & $\mathrm{n} / \mathrm{a}$ & $n / a$ \\
\hline $\begin{array}{l}\text { Age + Alcoholism + CLD + DM } \\
+ \text { Smoking }\end{array}$ & $<5$ & 0 & $\mathrm{n} / \mathrm{a}$ & $\mathrm{n} / \mathrm{a}$ \\
\hline $\begin{array}{l}\text { Age + Alcoholism + CLD + IC + } \\
\text { Smoking }\end{array}$ & $<5$ & $<5$ & 5.36 & $0.48-60.14$ \\
\hline $\begin{array}{l}\text { Age + Alcoholism + CRD + DM } \\
+ \text { IC }\end{array}$ & $<5$ & 0 & $\mathrm{n} / \mathrm{a}$ & $\mathrm{n} / \mathrm{a}$ \\
\hline $\begin{array}{l}\text { Age + Alcoholism + CRD + DM } \\
+ \text { Smoking }\end{array}$ & $5(0.06)$ & 0 & $\mathrm{n} / \mathrm{a}$ & $\mathrm{n} / \mathrm{a}$ \\
\hline $\begin{array}{l}\text { Age + Alcoholism + CRD + IC + } \\
\text { Smoking }\end{array}$ & $14(0.2)$ & $8(0.5)$ & 6.12 & $2.45-15.31^{*}$ \\
\hline $\begin{array}{l}\text { Age + Alcoholism + DM + IC + } \\
\text { Smoking }\end{array}$ & $<5$ & 0 & $\mathrm{n} / \mathrm{a}$ & $\mathrm{n} / \mathrm{a}$ \\
\hline $\mathrm{Age}+\mathrm{CHD}+\mathrm{CLD}+\mathrm{CRD}+\mathrm{DM}$ & $<5$ & $<5$ & 3.57 & $0.37-34.99$ \\
\hline $\mathrm{Age}+\mathrm{CHD}+\mathrm{CLD}+\mathrm{CRD}+\mathrm{IC}$ & $5(0.06)$ & $<5$ & 2.14 & $0.25-18.71$ \\
\hline $\begin{array}{l}\text { Age + CHD + CLD + CRD + } \\
\text { Smoking }\end{array}$ & $7(0.09)$ & $5(0.3)$ & 7.65 & $2.34-25.01^{*}$ \\
\hline $\mathrm{Age}+\mathrm{CHD}+\mathrm{CLD}+\mathrm{DM}+\mathrm{IC}$ & 0 & 0 & $\mathrm{n} / \mathrm{a}$ & $n / a$ \\
\hline $\begin{array}{l}\text { Age + CHD + CLD + DM + } \\
\text { Smoking }\end{array}$ & 0 & 0 & $\mathrm{n} / \mathrm{a}$ & $\mathrm{n} / \mathrm{a}$ \\
\hline $\begin{array}{l}\text { Age + CHD + CLD + IC + } \\
\text { Smoking }\end{array}$ & 0 & $<5$ & $\mathrm{n} / \mathrm{a}$ & $\mathrm{n} / \mathrm{a}$ \\
\hline $\mathrm{Age}+\mathrm{CHD}+\mathrm{CRD}+\mathrm{DM}+\mathrm{IC}$ & $81(1.0)$ & $39(2.2)$ & 5.16 & $3.19-8.35^{\star}$ \\
\hline $\begin{array}{l}\text { Age + CHD + CRD + DM + } \\
\text { Smoking }\end{array}$ & $79(1.0)$ & $19(1.1)$ & 2.58 & $1.443-4.60^{*}$ \\
\hline $\begin{array}{l}\text { Age + CHD + CRD + IC + } \\
\text { Smoking }\end{array}$ & $118(1.5)$ & $34(1.9)$ & 3.09 & $1.91-4.99^{*}$ \\
\hline $\begin{array}{l}\text { Age + CHD + DM + IC + } \\
\text { Smoking }\end{array}$ & $16(0.2)$ & $<5$ & 2.68 & $0.86-8.33$ \\
\hline $\mathrm{Age}+\mathrm{CLD}+\mathrm{CRD}+\mathrm{DM}+\mathrm{IC}$ & $<5$ & 0 & $\mathrm{n} / \mathrm{a}$ & $\mathrm{n} / \mathrm{a}$ \\
\hline $\begin{array}{l}\text { Age + CLD + CRD + DM + } \\
\text { Smoking }\end{array}$ & $<5$ & 0 & $\mathrm{n} / \mathrm{a}$ & $\mathrm{n} / \mathrm{a}$ \\
\hline $\begin{array}{l}\text { Age + CLD + CRD + IC + } \\
\text { Smoking }\end{array}$ & $<5$ & $<5$ & 16.07 & $2.62-98.50^{*}$ \\
\hline $\begin{array}{l}\text { Age + CLD + DM + IC + } \\
\text { Smoking }\end{array}$ & 0 & 0 & $\mathrm{n} / \mathrm{a}$ & $\mathrm{n} / \mathrm{a}$ \\
\hline $\begin{array}{l}\text { Age + CRD + DM + IC + } \\
\text { Smoking }\end{array}$ & $26(0.3)$ & $11(0.6)$ & 4.54 & $2.11-9.73^{*}$ \\
\hline
\end{tabular}




\begin{tabular}{|c|c|c|c|c|}
\hline $\begin{array}{l}\text { Alcoholism + CHD + CLD + } \\
\text { CRD + DM }\end{array}$ & $<5$ & 0 & $\mathrm{n} / \mathrm{a}$ & $\mathrm{n} / \mathrm{a}$ \\
\hline $\begin{array}{l}\text { Alcoholism + CHD + CLD + } \\
\text { CRD + IC }\end{array}$ & $<5$ & $<5$ & 10.71 & $0.66-173.96$ \\
\hline $\begin{array}{l}\text { Alcoholism + CHD + CLD + } \\
\text { CRD + Smoking }\end{array}$ & $13(0.2)$ & $<5$ & 3.30 & $1.04-10.50^{*}$ \\
\hline $\begin{array}{l}\text { Alcoholism + CHD + CLD + DM } \\
+ \text { IC }\end{array}$ & 0 & 0 & $\mathrm{n} / \mathrm{a}$ & $\mathrm{n} / \mathrm{a}$ \\
\hline $\begin{array}{l}\text { Alcoholism + CHD + CLD + DM } \\
+ \text { Smoking }\end{array}$ & $<5$ & $<5$ & 3.57 & $0.37-34.99$ \\
\hline $\begin{array}{l}\text { Alcoholism + CHD + CLD + IC + } \\
\text { Smoking }\end{array}$ & $<5$ & $<5$ & 10.71 & $0.66-173.96$ \\
\hline $\begin{array}{l}\text { Alcoholism + CHD + CRD + DM } \\
+ \text { IC }\end{array}$ & $<5$ & 0 & $\mathrm{n} / \mathrm{a}$ & $\mathrm{n} / \mathrm{a}$ \\
\hline $\begin{array}{l}\text { Alcoholism + CHD + CRD + DM } \\
+ \text { Smoking }\end{array}$ & $18(0.2)$ & $<5$ & 0.60 & $0.08-4.55$ \\
\hline $\begin{array}{l}\text { Alcoholism + CHD + CRD + IC } \\
+ \text { Smoking }\end{array}$ & $16(0.2)$ & $<5$ & 0.67 & $0.09-5.16$ \\
\hline $\begin{array}{l}\text { Alcoholism + CHD + DM + IC + } \\
\text { Smoking }\end{array}$ & $<5$ & 0 & $\mathrm{n} / \mathrm{a}$ & $n / a$ \\
\hline $\begin{array}{l}\text { Alcoholism + CLD + CRD + DM } \\
+ \text { IC }\end{array}$ & $<5$ & $<5$ & 10.71 & $0.66-173.96$ \\
\hline $\begin{array}{l}\text { Alcoholism + CLD + CRD + DM } \\
+ \text { Smoking }\end{array}$ & $10(0.1)$ & $<5$ & 2.14 & $0.46-10.06$ \\
\hline $\begin{array}{l}\text { Alcoholism + CLD + CRD + IC + } \\
\text { Smoking }\end{array}$ & $16(0.2)$ & $10(0.6)$ & 6.70 & $2.88-15.55^{*}$ \\
\hline $\begin{array}{l}\text { Alcoholism + CLD + DM + IC + } \\
\text { Smoking }\end{array}$ & $<5$ & $<5$ & 5.36 & $0.48-60.14$ \\
\hline $\begin{array}{l}\text { Alcoholism + CRD + DM + IC + } \\
\text { Smoking }\end{array}$ & $7(0.09)$ & 0 & $n / a$ & $n / a$ \\
\hline $\mathrm{CHD}+\mathrm{CLD}+\mathrm{CRD}+\mathrm{DM}+\mathrm{IC}$ & $<5$ & $<5$ & 10.71 & $0.66-173.96$ \\
\hline $\begin{array}{l}\text { CHD + CLD + CRD + DM + } \\
\text { Smoking }\end{array}$ & $8(0.1)$ & $<5$ & 4.02 & $1.03-15.64^{*}$ \\
\hline $\begin{array}{l}\text { CHD + CLD + CRD + IC + } \\
\text { Smoking }\end{array}$ & $<5$ & $<5$ & 7.14 & $1.17-43.78^{\star}$ \\
\hline $\begin{array}{l}\text { CHD + CLD + DM + IC + } \\
\text { Smoking }\end{array}$ & $5(0.06)$ & $<5$ & 4.29 & $0.81-22.68$ \\
\hline $\begin{array}{l}\text { CHD + CRD + DM + IC + } \\
\text { Smoking }\end{array}$ & $37(0.5)$ & $17(1.0)$ & 4.92 & $2.58-9.38^{*}$ \\
\hline $\begin{array}{l}\text { CLD + CRD + DM + IC + } \\
\text { Smoking }\end{array}$ & 0 & $<5$ & $\mathrm{n} / \mathrm{a}$ & $n / a$ \\
\hline Six Risk factors & $114(1.4)$ & $45(2.6)$ & 4.23 & $2.69-6.65^{\star}$ \\
\hline
\end{tabular}




\begin{tabular}{|c|c|c|c|c|}
\hline $\begin{array}{l}\text { Age + Alcoholism + CHD + CLD } \\
+ \text { CRD + IC }\end{array}$ & $<5$ & $<5$ & 10.71 & $0.66-173.96$ \\
\hline $\begin{array}{l}\text { Age + Alcoholism + CHD + CLD } \\
+ \text { CRD + Smoking }\end{array}$ & $5(0.06)$ & $<5$ & 4.29 & $0.81-22.68$ \\
\hline $\begin{array}{l}\text { Age + Alcoholism + CHD + CLD } \\
\text { + CRD + DM }\end{array}$ & $<5$ & $<5$ & 10.71 & $0.66-173.96$ \\
\hline $\begin{array}{l}\text { Age + Alcoholism + CHD + CLD } \\
+ \text { DM + IC }\end{array}$ & 0 & 0 & $\mathrm{n} / \mathrm{a}$ & $\mathrm{n} / \mathrm{a}$ \\
\hline $\begin{array}{l}\text { Age + Alcoholism + CHD + CLD } \\
+\mathrm{DM}+\text { Smoking }\end{array}$ & $<5$ & 0 & $\mathrm{n} / \mathrm{a}$ & $\mathrm{n} / \mathrm{a}$ \\
\hline $\begin{array}{l}\text { Age + Alcoholism + CHD + CLD } \\
+I C+\text { Smoking }\end{array}$ & 0 & $<5$ & $n / a$ & $n / a$ \\
\hline $\begin{array}{l}\text { Age + Alcoholism + CHD + } \\
\text { CRD + DM + IC }\end{array}$ & 0 & 0 & $\mathrm{n} / \mathrm{a}$ & $\mathrm{n} / \mathrm{a}$ \\
\hline $\begin{array}{l}\mathrm{Age}+\text { Alcoholism + CHD + } \\
\mathrm{CRD}+\mathrm{DM}+\text { Smoking }\end{array}$ & $11(0.1)$ & $<5$ & 2.92 & $0.79-10.83$ \\
\hline $\begin{array}{l}\text { Age + Alcoholism + CHD + } \\
\text { CRD + IC + Smoking }\end{array}$ & $13(0.2)$ & $7(0.4)$ & 5.77 & $2.20-15.13^{*}$ \\
\hline $\begin{array}{l}\text { Age + Alcoholism + CHD + DM } \\
+\mathrm{IC}+\text { Smoking }\end{array}$ & 0 & 0 & $\mathrm{n} / \mathrm{a}$ & $\mathrm{n} / \mathrm{a}$ \\
\hline $\begin{array}{l}\text { Age + Alcoholism + CLD + CRD } \\
+ \text { DM + IC }\end{array}$ & 0 & $<5$ & $\mathrm{n} / \mathrm{a}$ & $\mathrm{n} / \mathrm{a}$ \\
\hline $\begin{array}{l}\text { Age + Alcoholism + CLD + CRD } \\
+ \text { DM + Smoking }\end{array}$ & $<5$ & $<5$ & 10.71 & $0.66-173.96$ \\
\hline $\begin{array}{l}\text { Age + Alcoholism + CLD + CRD } \\
+ \text { IC + Smoking }\end{array}$ & $<5$ & $<5$ & 21.43 & $1.91-240.56^{*}$ \\
\hline $\begin{array}{l}\text { Age }+ \text { Alcoholism + CLD + DM } \\
+ \text { IC }+ \text { Smoking }\end{array}$ & 0 & 0 & $\mathrm{n} / \mathrm{a}$ & $\mathrm{n} / \mathrm{a}$ \\
\hline $\begin{array}{l}\text { Age + Alcoholism + CRD + DM } \\
+\mathrm{IC}+\text { Smoking }\end{array}$ & $<5$ & 0 & $\mathrm{n} / \mathrm{a}$ & $\mathrm{n} / \mathrm{a}$ \\
\hline $\begin{array}{l}\mathrm{Age}+\mathrm{CHD}+\mathrm{CLD}+\mathrm{CRD}+\mathrm{DM} \\
+\mathrm{IC}\end{array}$ & $<5$ & $<5$ & 5.36 & $0.96-29.99$ \\
\hline $\begin{array}{l}\text { Age + CHD + CLD + CRD + DM } \\
+ \text { Smoking }\end{array}$ & $<5$ & 0 & $\mathrm{n} / \mathrm{a}$ & $\mathrm{n} / \mathrm{a}$ \\
\hline $\begin{array}{l}\text { Age + CHD + CLD + CRD + IC } \\
+ \text { Smoking }\end{array}$ & $<5$ & $<5$ & 10.71 & $2.11-54.51^{*}$ \\
\hline $\begin{array}{l}\text { Age + CHD + CLD + DM + IC + } \\
\text { Smoking }\end{array}$ & 0 & 0 & $\mathrm{n} / \mathrm{a}$ & $\mathrm{n} / \mathrm{a}$ \\
\hline $\begin{array}{l}\text { Age + CHD + CRD + DM + IC + } \\
\text { Smoking }\end{array}$ & $34(0.4)$ & $10(0.6)$ & 3.15 & $1.47-6.76^{*}$ \\
\hline
\end{tabular}




\begin{tabular}{|c|c|c|c|c|}
\hline $\begin{array}{l}\text { Age + CLD + CRD + DM + IC + } \\
\text { Smoking }\end{array}$ & $<5$ & $<5$ & 5.36 & $0.48-60.14$ \\
\hline $\begin{array}{l}\text { Alcoholism + CHD + CLD + } \\
\text { CRD + DM + IC }\end{array}$ & $<5$ & 0 & $\mathrm{n} / \mathrm{a}$ & $\mathrm{n} / \mathrm{a}$ \\
\hline $\begin{array}{l}\text { Alcoholism + CHD + CLD + } \\
\text { CRD + DM + Smoking }\end{array}$ & $7(0.09)$ & $<5$ & 4.59 & $1.15-18.32^{*}$ \\
\hline $\begin{array}{l}\text { Alcoholism + CHD + CLD + } \\
\text { CRD + IC + Smoking }\end{array}$ & $6(0.08)$ & $<5$ & 7.14 & $1.95-26.17^{*}$ \\
\hline $\begin{array}{l}\text { Alcoholism + CHD + CLD + DM } \\
+\mathrm{IC}+\text { Smoking }\end{array}$ & $<5$ & 0 & $\mathrm{n} / \mathrm{a}$ & $\mathrm{n} / \mathrm{a}$ \\
\hline $\begin{array}{l}\text { Alcoholism + CHD + CRD + DM } \\
+\mathrm{IC}+\text { Smoking }\end{array}$ & $5(0.06)$ & $<5$ & 2.14 & $0.25-18.71$ \\
\hline $\begin{array}{l}\text { Alcoholism + CLD + CRD + DM } \\
+ \text { IC + Smoking }\end{array}$ & $<5$ & $<5$ & 5.36 & $0.96-29.99$ \\
\hline $\begin{array}{l}\text { CHD + CLD + CRD + DM + IC } \\
+ \text { Smoking }\end{array}$ & $<5$ & 0 & $n / a$ & $n / a$ \\
\hline Seven Risk factors & $13(0.2)$ & $<5$ & 2.47 & $0.68-8.98$ \\
\hline $\begin{array}{l}\text { Age + Alcoholism + CHD + CLD } \\
+ \text { CRD + DM + IC }\end{array}$ & $<5$ & 0 & $\mathrm{n} / \mathrm{a}$ & $\mathrm{n} / \mathrm{a}$ \\
\hline $\begin{array}{l}\text { Age + Alcoholism + CHD + CLD } \\
+ \text { CRD + DM + Smoking }\end{array}$ & 0 & $<5$ & $\mathrm{n} / \mathrm{a}$ & $\mathrm{n} / \mathrm{a}$ \\
\hline $\begin{array}{l}\text { Age + Alcoholism + CHD + CLD } \\
+ \text { CRD + IC + Smoking }\end{array}$ & $<5$ & 0 & $\mathrm{n} / \mathrm{a}$ & $\mathrm{n} / \mathrm{a}$ \\
\hline $\begin{array}{l}\text { Age + Alcoholism + CHD + CLD } \\
+\mathrm{DM}+\mathrm{IC}+\text { Smoking }\end{array}$ & 0 & $<5$ & $\mathrm{n} / \mathrm{a}$ & $n / a$ \\
\hline $\begin{array}{l}\text { Age + Alcoholism + CHD + } \\
\text { CRD + DM + IC + Smoking }\end{array}$ & $<5$ & 0 & $\mathrm{n} / \mathrm{a}$ & $\mathrm{n} / \mathrm{a}$ \\
\hline $\begin{array}{l}\text { Age + Alcoholism + CLD + CRD } \\
+\mathrm{DM}+\mathrm{IC}+\text { Smoking }\end{array}$ & $<5$ & $<5$ & 10.71 & $0.66-173.96$ \\
\hline $\begin{array}{l}\text { Age + CHD + CLD + CRD + DM } \\
+\mathrm{IC}+\text { Smoking }\end{array}$ & $<5$ & 0 & $\mathrm{n} / \mathrm{a}$ & $\mathrm{n} / \mathrm{a}$ \\
\hline $\begin{array}{l}\text { Alcoholism + CHD + CLD + } \\
\text { CRD + DM + IC + Smoking }\end{array}$ & $<5$ & 0 & $\mathrm{n} / \mathrm{a}$ & $\mathrm{n} / \mathrm{a}$ \\
\hline Eight Risk factors & $5(0.06)$ & $<5$ & 2.14 & $0.25-18.71$ \\
\hline $\begin{array}{l}\text { Age + Alcoholism + CHD + CLD } \\
+ \text { CRD + DM + IC + Smoking }\end{array}$ & $5(0.06)$ & $<5$ & 2.14 & $0.25-18.71$ \\
\hline
\end{tabular}

Age, Age $\geq 65$ years; CHD, Chronic Heart Disease; CLD, Chronic Liver Disease; CRD, Chronic Respiratory Disease; Cl, Confidence Interval; DM, Diabetes Mellitus; IC, Immunodeficiency; OR, Odds Ratio 
${ }^{*} \mathrm{p}<0.05$. 